ISSN 0258-7122 (Print), 2408-8293 (Online)

Bangladesh J. Agril. Res. 43(1): 1-12, March 2018

\title{
INFLUENCE OF PACLOBUTRAZOL ON GROWTH, YIELD AND QUALITY OF MANGO
}

\author{
B. C. SARKER ${ }^{1}$ AND M. A. RAHIM ${ }^{2}$
}

\begin{abstract}
A study on the effect of paclobutrazol on vegetative growth, harvest time, yield and quality of mango cv. BARI Mango-3 (Amrapali) was conducted at the Germplasm Centre, Department of Horticulture, Bangladesh Agricultural University, Mymensingh. Paclobutrazol @ 7500 ppm, 10000 ppm and control (water application) along with two application times; 15 July and 15 October were used with three replications following RCBD design. Paclobutrazol soil drenched @ 7500 ppm or 10000 ppm on 15 July distinctly advanced panicle emergence and fruit harvest by 23 and 22 days, respectively. Application of paclobutrazol @ 7500 ppm on 15 July produced the highest number of fruits $(185)$ as well as yield $(55.05 \mathrm{~kg})$ per plant and the biggest fruit $(303.67 \mathrm{~g})$. Paclobutrazol@7500 ppm applied on 15 July or 15 October also resulted in higher edible portion, lower stone pulp ratio, longer shelf life, higher TSS, increased vitamin $\mathrm{C}$, lower titratable acidity, higher dry matter, reducing, nonreducing and total sugar contents.
\end{abstract}

Keywords: Paclobutrazol, panicle emergence, fruit retention, edible portion, yield and quality.

\section{Introduction}

Mango (Mangifera indica L.), the king of fruits, predominantly grows in a short harvest period from May to June in Bangladesh. Irregular flowering, low fruit set as well as retention leading to low yield and fruits of poor quality are also the prevalent problems in mango production. The availability of fresh fruits after the normal fruiting season for a longer period, in addition to increasing yield and quality can be extended by using paclobutrazol. Soil application of paclobutrazol induces precocious flowering in young trees and promotes early flowering in bearing trees (Kulkarni, 1988). Inflorescence becomes visible within 2.5 to 4 months after the application of paclobutrazol depending on cultivar (Junthasri et al., 2000). PP333 (paclobutrazol) enhances the flower and fruit production in mango (Anbu et al., 2002). Improvement of fruit set and fruit retention in mango cv. Gulab Khas as well as the highest yield had been noticed under soil application of paclobutrazol (Singh and Singh, 2006). Paclobutrazol exhibits the pronounced effect on increasing the parameters like ascorbic acid, total sugar, reducing sugar and TSS, except for acidity in fruits of Alphonso mangoes at

${ }^{1}$ Principal Scientific Officer, Pomology Division, Horticulture Research Centre, Bangladesh Agricultural Research Institute (BARI), Joydebpur, Gazipur \& Former Fulbright Visiting Scholar, ${ }^{2}$ Professor, Department of Horticulture, Bangladesh Agriculture University (BAU), Mymensingh, Bangladesh. 
Coimbatore, India (Vijayalakshmi and Srinivasan, 2000). Mango trees treated with paclobutrazol had higher results for number of panicles produced, yield as well as quality of fruit compared to control (Yeshitela et al., 2004). Information regarding regulation of flowering and harvesting time, increasing yield and quality of mango using paclobutrazol is little or nil in Bangladesh. In order to extend the availability period as well as increasing yield and quality by adopting soil drench application of paclobutrazol in mango cv. BARI Aam-3 (Amrapali), the present study was undertaken.

\section{Materials and Methods}

The experiment was conducted at the Germplasm Centre, Department of Horticulture, Bangladesh Agricultural University, Mymensingh which is located at $24^{\circ} 26^{\prime}$ latitude and $90^{\circ} 15^{\prime}$ longitude with an altitude of $8.3 \mathrm{~m}$ above the sea level. Investigations related to bio-chemical analysis were carried out in the Department of Biochemistry of Bangladesh Agricultural University, Mymensingh. Ten years old BARI Aam-3 (Amrapali) plants with a plant spacing of $5 \times 5 \mathrm{~m}$ were included in the study. The factorial experiment was laid out in a Randomized Complete Block Design with three replications. Paclobutrazol (2RS,3RS)-1-(4-chlorophenyl)-4,4-dimethyl-2-(1,2,4-triazol-1-yl) pentan-3-ol @ 7500 and $10000 \mathrm{ppm}$ and control (water application) and two times of application (15 July and 15 October) were included in the study. By dissolving 30 and $40 \mathrm{ml}$ of $25 \%$ paclobutrazol (Syngenta Chem. Co. Ltd., India) into one litre of fresh water each, the solutions of 7500 and $10000 \mathrm{ppm}$ were prepared, respectively. Paclobutrazol solutions, each of 1 litre were soil drenched according to Burondkar \& Gunjate (1993), where 10 small holes (10-15 cm depth) were prepared in the soil around the collar region of the plants just inside the fertilizer ring. The prepared solutions of paclobutrazol as per treatment uniformly drenched into the holes and the soil was reworked after application of paclobutrazol. Only water (1 litre/plant) was applied in the control plants. The data of the following parameters were recorded: length of terminal shoot, number of leaves per terminal shoot, leaf area, length of panicle, number of secondary branches per panicle, date of first panicle emergence, total number of panicles, fruit set per panicle, number of fruits retained per panicle at 10 days interval starting from pea stage to harvest, date of harvest, number of fruits per plant, fruit weight, yield, edible portion, stone pulp ratio, peel pulp ratio, shelf-life, TSS, titratable acidity, vitamin $\mathrm{C}$, dry matter, reducing sugar, non reducing sugar and total sugar content. The length and number of leaves of ten randomly selected terminal shoots at flowering stage were measured and the average was worked out. Leaf area was measured for all the 50 leaves taking 5 from each of ten above selected shoots by a leaf area meter and expressed as square centimeter. The length and number of secondary branches per panicle of 10 randomly tagged panicles covering the whole tree was recorded and the average was worked out. Ten panicles were randomly selected from each treatment. The initial number of 
fruits of each panicle and the fruits retained per panicle at 10 day intervals starting from pea stage up to harvest were recorded and the average was worked out. After harvest, ten randomly selected fruits were allowed to ripen at room temperature and fruit quality was determined using 10 fruits per tree. Total Soluble Solid (TSS) of 10 fully ripened fruits for each treatment was estimated by a hand refractometer and the average was worked out. The titratable acidity (Ranganna, 1979), vitamin C (Plummer, 1971), reducing sugar (Miller, 1972) and total sugar content (Jayaraman, 1981) in mango pulp were determined. Data on different parameters of the experiment were tabulated and analyzed and the treatment means were separated by Least Significant Difference (LSD) test at 5 $\%$ level of significance.

\section{Results and Discussion}

\section{Combined effect on leaf, shoot and panicle characters of mango}

Date of first panicle emergence in different treatment combinations of paclobutrazol and time of application ranged from 09.12.06 to 01.01.07. Paclobutrazol applied either @ 7500 ppm or 10000 ppm on 15 July exhibited earlier panicle emergence compared to the delayed emergence in control. Regardless of concentration, paclobutrazol had earlier panicle emergence. Combined effect of paclobutrazol and time of application exhibited significant effect on terminal shoot length, number of leaves per terminal shoot, leaf area, panicle length, panicle breadth, number of secondary branches per panicle and number of panicles per plant (Table 1). Control plants had the longest terminal shoot $(21.00 \mathrm{~cm})$ treated on 15 October as against the shortest shoot $(6.43 \mathrm{~cm})$ from the plants treated with paclobutrazol @ 10000 ppm on 15 July. Control plants also exhibited maximum number of leaves (12.30) and leaf area (65.58 $\mathrm{cm}^{2}$ ) compared to minimum leaves per terminal shoot (9.10) and leaf area (44.51 $\mathrm{cm}^{2}$ ) in 10000 ppm paclobutrazol applied on 15 July. Paclobutrazol @ 7500 ppm on 15 July application resulted in maximum panicle length $(28.41 \mathrm{~cm})$ and panicle breadth $(26.92 \mathrm{~cm})$ and the control exhibited minimum panicle length $(22.63 \mathrm{~cm})$ and breadth $(20.92 \mathrm{~cm})$. Maximum secondary branches per panicle was obtained from the treatment combination of paclobutrazol @ 7500 ppm and 15 July application (36.30) followed by the combined effect of paclobutrazol @ $7500 \mathrm{ppm}$ and 15 October application (34.30), whereas the lowest value (26.25) was recorded in control. Maximum number of panicles per plant was obtained from the treatment combination of paclobutrazol @ 7500 ppm and 15 July (412.00), while it was noticed minimum in control (232.33). Regardless of application time and concentration, paclobutrazol suppressed vegetative growth compared to control. Paclobutrazol can enhance the total phenolic content of terminal buds that alter the phloem to xylem ratio of the stem, which is important in restricting the vegetative growth and enhancing flowering by altering assimilate partitioning and patterns of nutrient supply for new growth (Kurian 


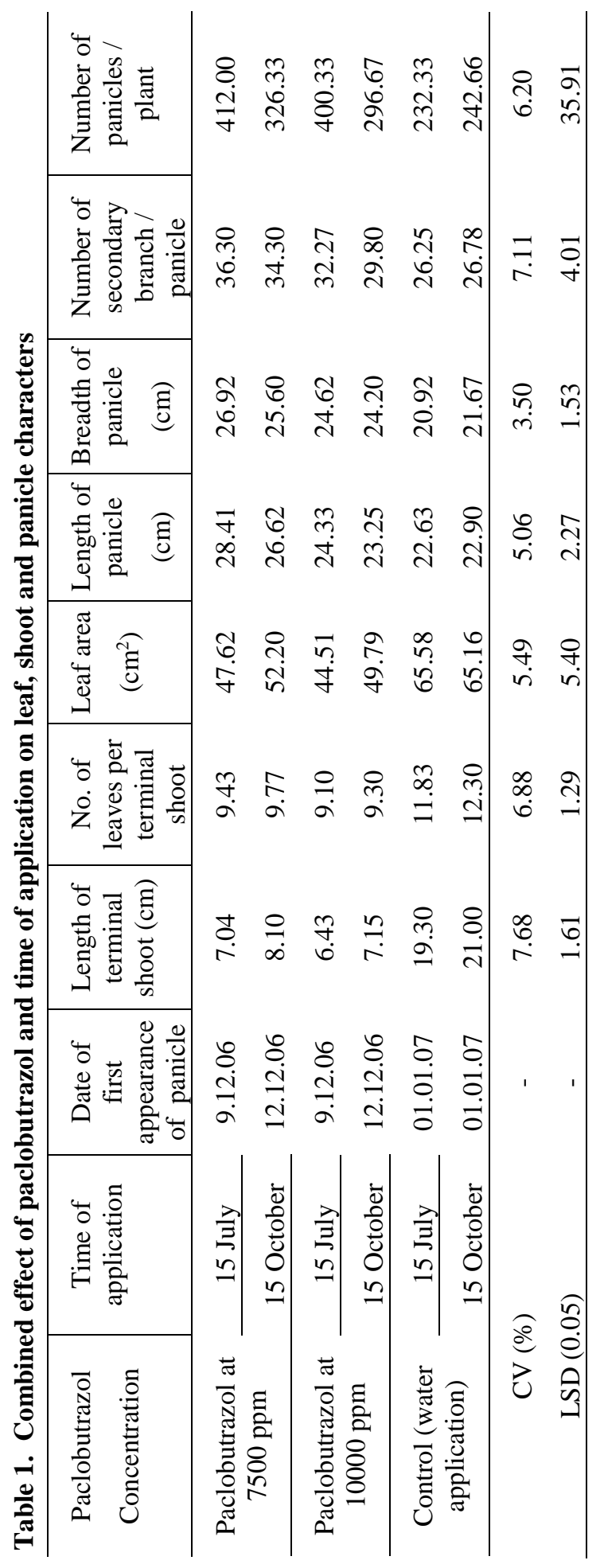


and Iyer, 1992). Soil drench applications of Cultar (Paclobutrazol) to mango cv. Dashehari at Ludhiana prior to flower bud differentiation during the first week of October affected the vegetative growth (Zora et al., 2000). The superior performances in terms of higher panicle length, panicle breadth and number of secondary branches per panicle in plants soil drenched with $7500 \mathrm{ppm}$ paclobutrazol on 15 July might be due to the optimum concentration and time of application of paclobutrazol. It is also probable that the application of paclobutrazol caused an early reduction of endogenous gibberellins levels within the shoots as also observed by Anon. (1984), causing them to reach maturity earlier than those of untreated trees. The total activity of auxin-like substances increased the higher starch reserve, total carbohydrates and higher $\mathrm{C}$ : $\mathrm{N}$ ratio in the shoots favoured flower bud initiation in mango. High level of auxins are necessary for flower bud differentiation in mango and this manipulation by sprays of synthetic substances at appropriate intervals may be helpful to induce flowering (Jogdande and Choudhari, 2001). In mango, it was found that PP333 exhibited auxin like activity and influenced the auxin synthesis. Regular, profuse and early bearing was also reported to be found due to paclobutrazol application in mango cv. Banganapalli grown in India (Singh and Ranganath, 2006). Paclobutrazol in general produced higher number of inflorescences per plant compared to control. Burondkar et al. (1997) also noted profuse flowering in paclobutrazol treated trees, when applied once during the month of July than untreated ones. A significant positive correlation between shoot total nonstructural carbohydrates (TNC) and number of flowers developed was observed by Phavaphutanon et al. (2000). Yeshitela et al. (2004) reported the increased number of panicles for paclobutrazol treated plants is due to lower expenditure of tree reserves to the vegetative growth parameters and consequently no assimilates limitations, compared with an excessive vegetative growth in the control trees. The application of paclobutrazol to soil antagonized gibberellin production in new shoots and induced flowering and fruiting (Ram, 1999).

\section{Combined effect on fruit set as well as fruit retention}

Among the treatment combinations, paclobutrazol applying @ 7500 ppm on 15 July manifested maximum fruit set per panicle (17.73), followed by paclobutrazol@ 7500 ppm on 15 October (16.60) and 10000 ppm and 15 July application (16.40) (Table 2). The control plants exhibited minimum fruit set (5.73). From 13 March 2007 to harvest, plants treated with paclobutrazol @ 7500 ppm on 15 July demonstrated maximum number of fruits per panicle and it was recorded 2.00 at harvest, which was followed by the combined effect of 10000 ppm paclobutrazol and 15 July (1.70). The control plants always recorded the least number of fruits per panicle and it was noted 0.60 at harvest. Trees Paclobutrazol treated trees had higher food reserves enhanced the highest fruit set compared to the lowest fruit set in the untreated tree with low reserves because of excessive vegetative growth (Yeshitela et al., 2004) corroborate the present 
result. Zora et al. (2000) revealed that cultar was the best treatment to promote flowering as well as fruit set in mango cv. Dashehari at Ludhiana, when applied in October.

Table 2. Combined effects of paclobutrazol and time of application on fruit set and fruit retention per panicle

\begin{tabular}{|c|c|c|c|c|c|c|}
\hline \multirow{2}{*}{$\begin{array}{l}\text { Paclobutrazol } \\
\text { Concentration }\end{array}$} & \multirow{2}{*}{$\begin{array}{c}\text { Time of } \\
\text { application }\end{array}$} & \multirow{2}{*}{$\begin{array}{l}\text { Fruit set per } \\
\text { panicle }\end{array}$} & \multicolumn{4}{|c|}{ Number of fruits retained per panicle at } \\
\hline & & & 13.03 .07 & 23.03 .07 & 02.04 .07 & 12.04 .07 \\
\hline \multirow{2}{*}{$\begin{array}{l}\text { Paclobutrazol at } \\
7500 \mathrm{ppm}\left(\mathrm{P}_{1}\right)\end{array}$} & 15 July & 17.73 & 6.03 & 4.40 & 2.93 & 2.70 \\
\hline & 15 October & 16.60 & 5.10 & 3.80 & 2.33 & 1.82 \\
\hline \multirow{2}{*}{$\begin{array}{l}\text { Paclobutrazol at } \\
10000 \mathrm{ppm}\left(\mathrm{P}_{2}\right)\end{array}$} & 15 July & 16.40 & 4.80 & 3.70 & 2.83 & 2.30 \\
\hline & 15 October & 13.65 & 4.00 & 3.05 & 2.10 & 1.30 \\
\hline \multirow{2}{*}{$\begin{array}{l}\text { Control (water } \\
\text { application) }\left(\mathrm{P}_{3}\right)\end{array}$} & 15 July & 5.73 & 2.79 & 2.80 & 1.93 & 1.25 \\
\hline & 15 October & 6.63 & 1.80 & 2.83 & 2.03 & 1.27 \\
\hline \multicolumn{2}{|c|}{$\mathrm{CV}(\%)$} & 5.57 & 8.86 & 11.16 & 11.04 & 5.80 \\
\hline \multicolumn{2}{|c|}{$\operatorname{LSD}(0.05)$} & 1.30 & 0.66 & 0.69 & 0.27 & 0.19 \\
\hline
\end{tabular}

Table 2 contd.

\begin{tabular}{|c|c|c|c|c|c|c|c|}
\hline \multirow{2}{*}{$\begin{array}{l}\text { Paclobutrazol } \\
\text { concentration }\end{array}$} & \multirow{2}{*}{$\begin{array}{c}\text { Time of } \\
\text { application }\end{array}$} & \multicolumn{6}{|c|}{ Number of fruits retained per panicle at } \\
\hline & & 22.04 .07 & 02.05 .07 & 12.05 .07 & 22.05 .07 & 01.06 .07 & Harvest \\
\hline \multirow{2}{*}{$\begin{array}{l}\text { Paclobutrazol at } \\
7500 \text { ppm }\left(\mathrm{P}_{1}\right)\end{array}$} & 15 July & 2.30 & 2.10 & 2.00 & 2.00 & 2.00 & 2.00 \\
\hline & 15 October & 1.73 & 1.47 & 1.47 & 1.47 & 1.44 & 1.44 \\
\hline \multirow{2}{*}{$\begin{array}{l}\text { Paclobutrazol at } \\
10000 \mathrm{ppm}\left(\mathrm{P}_{2}\right)\end{array}$} & 15 July & 2.10 & 2.00 & 1.80 & 1.77 & 1.73 & 1.70 \\
\hline & 15 October & 1.23 & 1.03 & 1.00 & 1.00 & 1.00 & 1.00 \\
\hline \multirow{2}{*}{$\begin{array}{l}\text { Control (water } \\
\text { application) }\left(\mathrm{P}_{3}\right)\end{array}$} & 15 July & 1.17 & 0.77 & 0.70 & 0.67 & 0.67 & 0.60 \\
\hline & 15 October & 1.20 & 0.80 & 0.70 & 0.67 & 0.67 & 0.67 \\
\hline \multicolumn{2}{|c|}{$\mathrm{CV}(\%)$} & 9.39 & 9.81 & 7.84 & 8.70 & 7.39 & 7.78 \\
\hline \multicolumn{2}{|c|}{ LSD $(0.05)$} & 0.27 & 0.24 & 0.18 & 0.20 & 0.17 & 0.17 \\
\hline
\end{tabular}

\section{Combined effect on date of harvest, number of fruits, fruit characters, yield and shelf life}

Paclobutrazol in general exhibited earlier harvest than that of the control. Induction of early flowering may also advance fruit maturity (Burondkar \& Gunjate 1993). Spraying of paclobutrazol in late August/early September in the southwestern part of Hainan province, China promoted flowering and ripening date (Xie et al., 1999). The advancement of harvesting time in case of paclobutrazol application in mango cv. Banganapalli has been reported in India (Singh and Ranganath, 2006). The combined effect of paclobutrazol and time of application was found significant in respect of number of fruits per plant, fruit weight, fruit length, fruit breadth, fruit thickness, stone pulp ratio, yield and shelf-life but edible portion and peel pulp ratio did not exhibit significant variation (Table 3 and Fig. 1). The number of fruits per plant was noticed to be the highest (185.33) in the treatment combination of $7500 \mathrm{ppm}$ paclobutrazol and 15 July application and the second highest number of fruits was manifested from 
10000 ppm paclobutrazol when applied on 15 July (157.12), whereas the control produced the lowest fruits (66.99). Paclobutrazol when soil drenched @7500 ppm on 15 July resulted in the highest fruit weight $(303.67 \mathrm{~g})$, which was statistically identical to that of the combination of $7500 \mathrm{ppm}$ and 15 October application $(293.33 \mathrm{~g})$, as compared to the lowest fruit weight $(177.00 \mathrm{~g})$ in the control. The paclobutrazol treated plants @ 7500 ppm on 15 July resulted in the highest fruit length $(11.10 \mathrm{~cm})$ while the control plants had the least fruit length $(8.89 \mathrm{~cm})$. The highest fruit breadth $(7.41 \mathrm{~cm})$ was recorded from the treatment combination of $7500 \mathrm{ppm}$ paclobutrazol and 15 July application as against minimum value with $6.37 \mathrm{~cm}$ in control. Fruit thickness was recorded the highest $(6.84 \mathrm{~cm})$ in the combination of paclobutrazol @ 7500 ppm and 15 July application as against the lowest thickness $(5.85 \mathrm{~cm})$ in control. The plants soil drenched with paclobutrazol @ 7500 ppm combined with 15 July or 15 October application registered the lowest and same stone pulp ratio of 0.22 as compared to the highest ratio (0.29) in control. The increased fruit weight in paclobutrazol treated plants might be due to the increased rate of photosynthesis and an increase in chlorophyll content. Quinlan (1981) opined that paclobutrazol increased the water use efficiency in photosynthesis of leaves by increasing the rate of photosynthesis for a given level of leaf stomatal conductance or transpiration. Paclobutrazol in general caused an increase in fruit number as well as yield per plant compared to control. A significantly higher fruit set and fruit retention in the paclobutrazol treated plants had a favourable impact on culminating higher final fruit number and yield per plant. Paclobutrazol has been reported to exert influence on partitioning the photosynthates to the sites of flowering and fruit production consequent to the reduction of vegetative growth. In this context, Kurian et al. (2001) reported that paclobutrazol appeared to favourably alter the source sink relationship of mango to support fruit growth with a reduction in vegetative growth.

Table 3. Combined effect of paclobutrazol and time of application on number of fruits and fruit characters

\begin{tabular}{|c|c|c|c|c|c|c|c|}
\hline \multirow[b]{2}{*}{$\begin{array}{l}\text { Paclobutrazol } \\
\text { concentration }\end{array}$} & \multirow[b]{2}{*}{$\begin{array}{c}\text { Time of } \\
\text { application }\end{array}$} & \multirow[b]{2}{*}{$\begin{array}{l}\text { Date of } \\
\text { harvest }\end{array}$} & \multirow{2}{*}{$\begin{array}{l}\text { Number of } \\
\text { fruits per } \\
\text { plant }\end{array}$} & \multicolumn{4}{|c|}{ Fruit } \\
\hline & & & & $\begin{array}{l}\text { Weight } \\
(\mathrm{g})\end{array}$ & $\begin{array}{l}\text { Length } \\
(\mathrm{cm})\end{array}$ & $\begin{array}{l}\text { Breadth } \\
(\mathrm{cm})\end{array}$ & $\begin{array}{c}\text { Thickness } \\
(\mathrm{cm})\end{array}$ \\
\hline \multirow{2}{*}{$\begin{array}{l}\text { Paclobutrazol at } \\
7500 \text { ppm }\left(\mathrm{P}_{1}\right)\end{array}$} & 15 July & 04.06 .06 & 185.33 & 303.67 & 11.10 & 7.41 & 6.84 \\
\hline & 15 October & 04.06 .06 & 140.78 & 293.33 & 10.99 & 7.29 & 6.68 \\
\hline \multirow{2}{*}{$\begin{array}{l}\text { Paclobutrazol at } \\
10000 \mathrm{ppm}\left(\mathrm{P}_{2}\right)\end{array}$} & 15 July & 04.06 .06 & 157.12 & 260.67 & 10.22 & 7.17 & 6.39 \\
\hline & 15 October & 04.06 .06 & 93.50 & 239.47 & 9.84 & 6.93 & 6.30 \\
\hline \multirow{2}{*}{$\begin{array}{l}\text { Control (water } \\
\text { application) }\left(\mathrm{P}_{3}\right)\end{array}$} & 15 July & 26.06 .06 & 66.99 & 177.00 & 8.89 & 6.37 & 5.85 \\
\hline & 15 October & 26.06 .06 & 68.25 & 178.33 & 8.95 & 6.38 & 5.88 \\
\hline \multicolumn{2}{|c|}{$\mathrm{CV}(\%)$} & - & 4.29 & 3.69 & 5.04 & 4.51 & 5.02 \\
\hline \multicolumn{2}{|c|}{$\operatorname{LSD}(0.05)$} & - & 9.26 & 16.25 & 0.92 & 0.57 & 0.58 \\
\hline
\end{tabular}


Table 3 contd.

\begin{tabular}{|c|c|c|c|c|c|}
\hline $\begin{array}{l}\text { Paclobutrazol } \\
\text { Concentration }\end{array}$ & $\begin{array}{c}\text { Time of } \\
\text { application }\end{array}$ & $\begin{array}{c}\text { Edible } \\
\text { portion }(\%)\end{array}$ & $\begin{array}{l}\text { Stone pulp } \\
\text { ratio }\end{array}$ & $\begin{array}{l}\text { Peel pulp } \\
\text { ratio }\end{array}$ & $\begin{array}{c}\text { Shelf life } \\
\text { (days) }\end{array}$ \\
\hline \multirow{2}{*}{$\begin{array}{l}\text { Paclobutrazol at } \\
7500 \mathrm{ppm}\left(\mathrm{P}_{1}\right)\end{array}$} & 15 July & 69.55 & 0.22 & 0.23 & 9.67 \\
\hline & 15 October & 68.76 & 0.22 & 0.24 & 9.17 \\
\hline \multirow{2}{*}{$\begin{array}{l}\text { Paclobutrazol at } \\
10000 \mathrm{ppm}\left(\mathrm{P}_{2}\right)\end{array}$} & 15 July & 68.09 & 0.23 & 0.23 & 9.50 \\
\hline & 15 October & 66.80 & 0.25 & 0.24 & 9.33 \\
\hline \multirow{2}{*}{$\begin{array}{l}\text { Control (water } \\
\text { application) }\left(\mathrm{P}_{3}\right)\end{array}$} & 15 July & 65.82 & 0.28 & 0.23 & 7.67 \\
\hline & 15 October & 65.95 & 0.29 & 0.23 & 8.00 \\
\hline \multicolumn{2}{|c|}{$\mathrm{CV}(\%)$} & 3.67 & 8.81 & 5.59 & 5.95 \\
\hline \multicolumn{2}{|c|}{$\operatorname{LSD}(0.05)$} & - & 0.04 & - & 3.23 \\
\hline
\end{tabular}

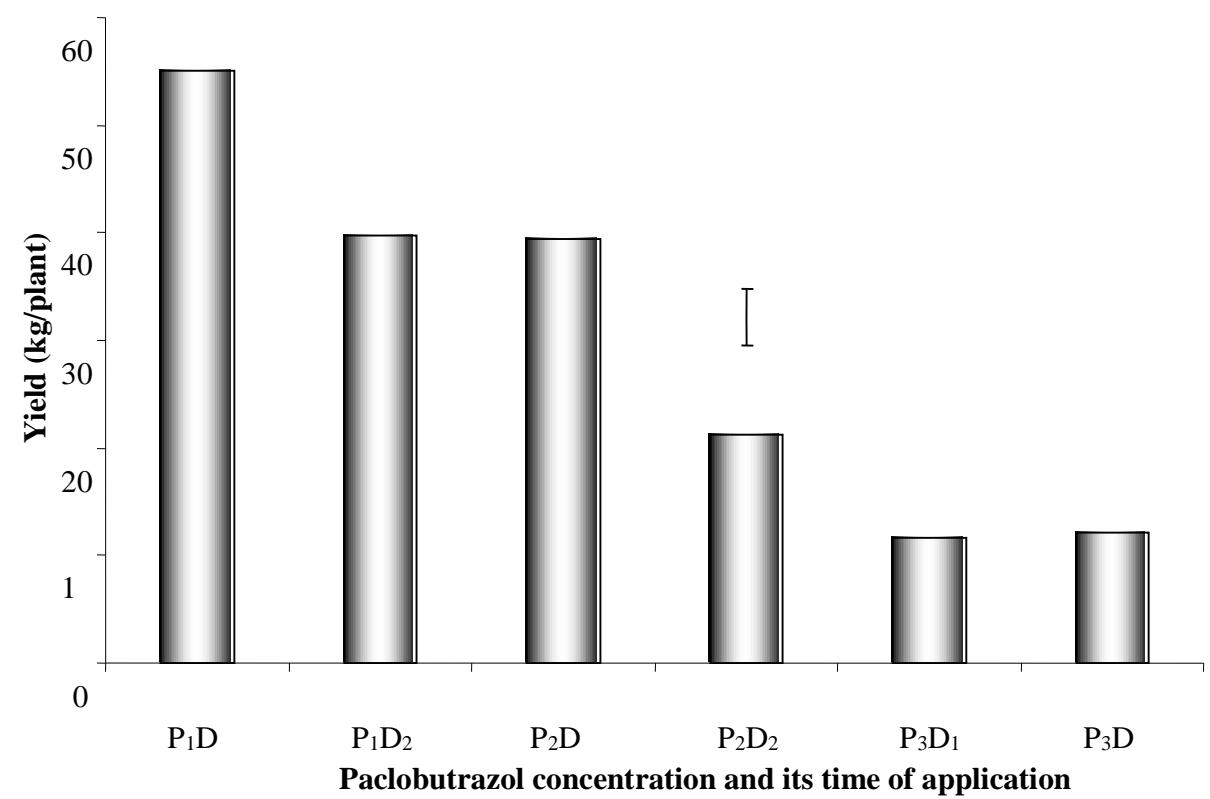

Figure 1. Effect of paclobutrazol and time of application on the yield per plant of mango Vertical bar represents LSD at $5 \%$ level
$\mathrm{P}_{1}$ : Paclobutrazol @ 7500 ppm
$\mathrm{D}_{1}: 15$ July application
$\mathrm{P}_{2}$ : Paclobutrazol @ 10000 ppm
$\mathrm{D}_{2}: 15$ October application
$\mathrm{P}_{3}$ : Control (water application)

The treatment combination of 7500 ppm paclobutrazol and 15 July application exhibited maximum fruit yield $(55.05 \mathrm{~kg} / \mathrm{plant})$. The next higher but statistically identical yield (39.77 and $39.40 \mathrm{~kg} / \mathrm{plant}$ ) were noticed from the treatment 
combinations of $7500 \mathrm{ppm}$ and 15 October and $10000 \mathrm{ppm}$ and $15 \mathrm{July}$, respectively. The control plants showed minimum $(11.72 \mathrm{~kg} / \mathrm{plant})$ yield. Paclobutrazol@ $@ 7500$ ppm combined with 15 July application exhibited the highest shelf life (9.67 days) as compared to the lowest value with 7.67 days in control. Moreover, the effect of paclobutrazol on increasing the chlorophyll content of leaves, besides influencing the $\mathrm{CO}_{2}$ assimilation might manifest higher photosynthetic efficiency leading to higher accumulation of carbohydrates, that might have influence on higher fruit bud initiation, flowering, fruit set and yield (Richardson and Quinlan, 1986). Plants treated with paclobutrazol in mango cv. Langra in India produced the highest number of fruits and yield (Karuna et al., 2005; Karuna et al., 2007).

\section{Combined effect on fruit quality}

There were profound variations in respect of TSS, titratable acidity, vitamin C, dry matter content; reducing, non reducing and total sugar due to the combined effect of paclobutrazol and time of application, while $\mathrm{pH}$ and moisture content did not exhibit significant differences (Table 4). Plants soil drenched with paclobutrazol @ 7500 ppm on 15 July recorded the highest TSS content (28.00\%) compared to the lowest TSS in control (22.27\%). The lowest value of the titratable acidity with 0.19 was exhibited when paclobutrazol @ 10000 ppm was applied to the plants on $15 \mathrm{July}$, whereas the highest value (0.24) appeared in the control. Paclobutrazol when applied @ 7500 ppm on 15 July resulted in maximum vitamin $\mathrm{C}$ content $(35.02 \mathrm{mg} / 100 \mathrm{~g}$ pulp), while control plants had minimum vitamin $\mathrm{C}$ content $(28.73 \mathrm{mg} / 100 \mathrm{~g}$ pulp).

Table 4. Combined effect of paclobutrazol and time of application on quality attributes

\begin{tabular}{|c|c|c|c|c|c|}
\hline $\begin{array}{l}\text { Paclobutrazol } \\
\text { Concentration }\end{array}$ & $\begin{array}{l}\text { Time of } \\
\text { application }\end{array}$ & $\begin{array}{l}\text { TSS } \\
(\%)\end{array}$ & $\mathrm{pH}$ & $\begin{array}{c}\text { Titratable } \\
\text { acidity (\%) }\end{array}$ & $\begin{array}{c}\text { Vitamin C } \\
\text { (mg/100 g pulp) }\end{array}$ \\
\hline \multirow{2}{*}{$\begin{array}{l}\text { Paclobutrazol at } \\
7500 \mathrm{ppm}\end{array}$} & 15 July & 28.00 & 6.13 & 0.20 & 35.02 \\
\hline & 15 October & 26.53 & 6.30 & 0.22 & 34.73 \\
\hline \multirow{2}{*}{$\begin{array}{l}\text { Paclobutrazol at } \\
10000 \mathrm{ppm}\end{array}$} & 15 July & 25.13 & 6.02 & 0.19 & 33.72 \\
\hline & 15 October & 24.57 & 6.09 & 0.20 & 32.96 \\
\hline \multirow{2}{*}{$\begin{array}{c}\text { Control (water } \\
\text { application) }\end{array}$} & 15 July & 22.27 & 5.55 & 0.23 & 28.73 \\
\hline & 15 October & 22.47 & 5.79 & 0.24 & 28.90 \\
\hline \multicolumn{2}{|c|}{$\mathrm{CV}(\%)$} & 6.56 & 4.73 & 5.87 & 3.82 \\
\hline \multicolumn{2}{|c|}{$\operatorname{LSD}(0.05)$} & 2.96 & - & 0.03 & 2.25 \\
\hline
\end{tabular}


Table 4 contd.

\begin{tabular}{|c|c|c|c|c|c|c|}
\hline $\begin{array}{l}\text { Paclobutrazol } \\
\text { concentration }\end{array}$ & $\begin{array}{c}\text { Time of } \\
\text { application }\end{array}$ & $\begin{array}{c}\text { Moisture } \\
\text { content } \\
(\%)\end{array}$ & $\begin{array}{c}\text { Dry matter } \\
\text { content } \\
(\%)\end{array}$ & $\begin{array}{c}\text { Reducing } \\
\text { sugar } \\
(\%)\end{array}$ & $\begin{array}{c}\text { Non } \\
\text { reducing } \\
\text { sugar }(\%)\end{array}$ & $\begin{array}{c}\text { Total } \\
\text { sugar } \\
(\%)\end{array}$ \\
\hline \multirow{2}{*}{$\begin{array}{l}\text { Paclobutrazol at } \\
7500 \text { ppm }\end{array}$} & 15 July & 78.01 & 21.99 & 5.42 & 13.95 & 19.37 \\
\hline & 15 October & 79.78 & 20.22 & 5.35 & 13.87 & 19.22 \\
\hline \multirow{2}{*}{$\begin{array}{l}\text { Paclobutrazol at } \\
10000 \mathrm{ppm}\end{array}$} & 15 July & 81.15 & 18.85 & 5.21 & 13.50 & 18.71 \\
\hline & 15 October & 81.93 & 18.07 & 5.15 & 13.44 & 18.59 \\
\hline \multirow{2}{*}{$\begin{array}{l}\text { Control (water } \\
\text { application) }\end{array}$} & 15 July & 83.61 & 17.39 & 4.81 & 12.48 & 17.30 \\
\hline & 15 October & 81.56 & 17.44 & 4.76 & 12.43 & 17.19 \\
\hline \multicolumn{2}{|c|}{$\mathrm{CV}(\%)$} & 2.61 & 4.67 & 3.00 & 2.93 & 2.91 \\
\hline \multicolumn{2}{|c|}{$\operatorname{LSD}(0.05)$} & - & 1.61 & 0.28 & 0.71 & 0.97 \\
\hline
\end{tabular}

Paclobutrazol applied at $7500 \mathrm{ppm}$ on 15 July exhibited maximum dry matter (21.99\%) compared to the lowest value with $17.39 \%$ in control. Reducing sugar content was recorded the highest $(5.42 \%)$ in the plants treated with paclobutrazol @ $7500 \mathrm{ppm}$ on 15 July as against the lowest content $(4.76 \%)$ in control. Paclobutrazol irrespective of concentration and time of application produced higher reducing sugar content compared to control. Fruits from the plants treated with paclobutrazol @ 7500 ppm on 15 July contained maximum non reducing sugar $(13.95 \%)$, whereas control plants showed minimum sugar $(12.43 \%)$. Soil drenched with paclobutrazol @ 7500 ppm on 15 July resulted in maximum total sugar content of $19.37 \%$ as against minimum sugar (17.19\%) in control. All the treatment combinations except control were statistically identical and demonstrated higher total sugar. Improvement in fruit quality in respect of TSS, TSS to acid ratio, total sugar and reducing sugar in response to paclobutrazol can be related to assimilate partitioning of the plant. Due to higher suppression of vegetative growth, assimilates need to become unidirectional towards developing fruit, as a result paclobutrazol treated trees exhibited higher fruit quality attributes. With the same justification, the control trees had lower TSS and sugars but higher titratable acidity. Paclobutrazol improved fruit quality (Vijayalakshmi \& Sirivasan, 1998; Hoda et al., 2001 and Yeshitela et al., 2004). Vijayalakshmi and Srinivasan (2000) reported that paclobutrazol in Alphonso mangoes in India had the greatest effect enhancing all the qualitative parameters (ascorbic acid, total sugar, reducing sugar and TSS, except for acidity) in harvested fruits. Soil treatment with paclobutrazol improved the fruit quality attributes (Singh and Singh, 2006).

\section{Conclusion}

The result revealed that soil drenched with paclobutrazol either at $7500 \mathrm{ppm}$ or 10000 ppm on 15 July advanced panicle emergence as well as harvest in mango cv. BARI Aam-3 (Amrapali) by 23 and 22 days, respectively, which will in turn 
help the growers in extending the availability period of mango. Paclobutrazol @ $7500 \mathrm{ppm}$ on 15 July exhibited superior results pertaining to fruit yield and quality.

\section{References}

Anbu, S., S. Parthiban, J. Rajangam and T. Thangaraj. 2002. Induction of off season flowering in mango (Mangifera indica L.) using paclobutrazol. South Indian Hort. 49 (Special): 384-385.

Anonymous. 1984. Paclobutrazol, plant growth regulator for fruit. London, Fern Hurst, I.C.I. (Plant Protection Division). P. 35.

Burondkar, M. M. and R. T. Gunjate. 1993. Control of vegetative growth and induction of regular and early cropping in 'Alphonso' mango with paclobutrazol. Acta Hort., 341: 206-215.

Burondkar, M. M., R. T. Gunjate, M. B. Magdum, M. A. Govekar and G. M. Waghmare. 1997. Increasing productivity of mango orchards by pruning and application of paclobutrazol. Acta Hort. 455: 367-374.

Hoda, M. N., S. Sanjay, S. Jayant, S. Singh and J. Singh. 2001. Effect of cultar on flowering, fruiting and fruit quality of mango cv. Langra. Indian J. Hort. 58 (3): 224227.

Jayaraman, J. 1981. Laboratoy Mannual in Biochemistry. Wiley Eastern Ltd., New Delhi, India. p. 62.

Jogdande, N. D. and K. G. Choudhari. 2001. Seasonal changes in auxin content and its role in flowering of mango (Mangifera indica L.). Orissa J.Hort. 29 (2): 10-12.

Junthasri, R., P. Nartvaranant, S. Subhadrabandhu and P. Tongumpai. 2000. Flower induction for producing off-season mango in Thailand. J. Appl. Hort. 2(1): 65-70.

Karuna, K., A. Mankar and J. Singh. 2005. Effect of urea and growth substances on yield and physico-chemical characteristics of mango. Hort. J. 18(3): 131-133.

Karuna, K., A. Mankar and J. Singh. 2007. Effect of urea and growth substances on yield and quality of mango cv. Langra. Orissa J. Hort. 35(1): 67-70.

Kulkarni,V. J. 1988. Chemical control of tree and promotion of flowering and fruiting in mango (Mangifera indica L.) using paclobutrazol. J. Hort. Sci. 63: 557-566.

Kurian, R. M. and C. P. A. Iyer. 1992. Stem anatomical characteristics in relation to tree vigour in mango (Mangifera indica L.). Scientia Hort. 50: 245-253.

Kurian, R. M., Y. T. N. Reddy, R. K. Sonkar and V. V. P.Reddy. 2001. Effect of paclobutrazol on source- sink relationship in mango (Mangifera indica L.). J. Appl. Hort. 3(2): 88-90.

Miller, G. L. 1972. Use of Dinitro Salicylic Acid Reagent for determination of reducing sugar. Anal. Chem. 31: 426-428.

Phavaphutanon, L., K. Krisanapook, A. Pichakum, K. Jutamanee, L. Phavaphutanon; K. Krisanapook, A. Pichakum, K. Jutamanee, S. Subhadrabandhu (ed.) and A. Pichakum. 2000. Changes of total non-structural carbohydrates within shoots of 'Nam Dok Mai' mango after paclobutrazol application. Acta Hort. 509: 559-565. 
Plummer, D. T. 1971. An Introduction to Practical Biochemistry. Tata McGraw Hill Pub. Com: Ltd. Bombay, New Delhi. P. 229.

Quinlan, J. D. 1981. New approaches to the control of fruit tree forms and size. Acta Hort. 120: 95-105.

Ram, S. 1999. Hormonal physiology of flowering in 'Dashehari' mango. J. Appl. Hort., 1(2) 84-88.

Rangana, S. 1979. Mannual of Analysis of fruit and Vegetable Products. Tata McGrawHill Pub. Co. Ltd., New Delhi. P. 634.

Richardson, P. J. and J. D. Quinlan, 1986. Uptake and translocation of paclobutrazol by shoots of M 26 apple rootstock. Plant Growth Regul. 4: 347-356.

Rojas, E., F. Leal and R. J. Campbell. 1993. Control of flowering and shooting in mango (Mangifera indica L.) with various chemical products. Proceedings of the International Society for Tropical and Tropical Horticulture. 37:142-147.

Singh, D. B and H. R. Ranganath. 2006. Induction of regular and early fruiting in mango by paclobutrazol under tropical humid climate. Indian J. Hort. 63(3): 248-250.

Singh, S. and A. K. Singh. 2006. Regulation of shoot growth and flowering in mango cv. Gulab Khas by paclobutrazol. Annals Agric. Res. 27(1): 4-8.

Vijayalakshmi, D. and P. S. Srinivasan. 1998. Induction of flowering in 'off' year mango cv. Alphonso as influenced by chemicals and growth regulators. Annals Plant Physiol. 12 (2): 93-97.

Vijayalakshmi, D. and P. S. Srinivasan. 2000. Improving the quality attributes of 'off' year Alphonso mango through chemicals and growth regulators. Orissa J. Hort. 28 (1): 31-33.

Xie, G. G., B. Q. Xie, G. G. Xie and B. Q. Xie. 1999. Key cultural techniques for high production and quality from mango trees. South China Fruits. 28 (3): 25-26.

Yeshitela, T., P. J. Robbertse and P. J. C. Stassen. 2004. Paclobutrazol suppressed vegetative growth and improved yield as well as fruit quality of 'Tommy Atkins' mango (Mangifera indica) in Ethiopia. New Zealand J. Crop and Hort. Sci. 32(3): 281-293.

Zora, S., Z. Singh, W. Muller, F. Polesny, C. Verheyden and A. D. Webster. 2000. Effect of Paclobutrazol on tree vigour, flowering, fruit set and yield in mango. Acta Hort. 525: 459- 462. 